\title{
THE IMAGE-PARADIGM OF JERUSALEM IN CHRISTIAN HIEROTOPY
}

\author{
Andrew Simsky \\ Research Center for Eastern Christian Culture, Moscow, Russia \\ andrew_simsky@mail.ru
}

Image-paradigms are non-pictorial mental images of the sacred. They are engendered in the viewer's imagination by means of organized ensembles of iconic, symbolic and typological elements of sacred spaces and emerge from a manifold of interrelating associations. In this paper I elucidate this complex notion by studying the example of one image-paradigm of fundamental importance, namely, the Holy City of Jerusalem, which appears to the religious imagination as the synthesis of an idealized historical city-relic and its celestial counterpart - the Heavenly Jerusalem. This Jerusalem is both the 'navel' of the world and a place of God's immediate, living presence. The Church as a whole, as well as individual churches, are identified with Jerusalem, which reflects their primary function of serving as meeting places with God. While participating in the liturgy and integrating into the liturgical space, the faithful feel themselves to be in the midst of the Heavenly Jerusalem, a feeling which clearly cannot be reduced to or evoked by a simple two-dimensional picture. Generally, pictures are unable fully to represent a sense of being somewhere. They help to create ambiences, but they cannot represent them. It takes more than a pictorial representation to transport oneself, in the mind's eye, to another place. This is what is involved in the concept of the image-paradigm. The image-paradigm works by means of a 'spatial icon', that is, a thoughtfully arranged spatial system of pointers, including architecture, an iconographic program, as well as the entire liturgical performance, including the very presence of the congregation absorbed in pious contemplation. An image-paradigm belongs to the religious tradition as a whole and takes shape in individual minds through a wide variety of religious experiences, including training, reading, prayer, liturgical life, mysticism, etc. An image-paradigm can be evoked in sacred spaces only because it is known beforehand to all the actors involved, both to those arranging them as well as viewers. In this paper, I begin with a brief review of iconographic strategies employed in conjuring the image-paradigm of the Holy City in Christian churches. In particular, the Celestial City can be represented in icons by means of earthly architecture including either recognizable motives of Constantinian Jerusalem or idealized and even fantastic patterns. Next, I move on to New Jerusalems, that is, Medieval re-constructions of the Christian Jerusalem, which were used as sites of virtual pilgrimage. Finally, I discuss possible links between Russian onion domes and the cupola of most prominent Jerusalem churches: the Holy Sepulcher and the Dome of the Rock. Particularly, I show how the famous cathedral of St. Basil the Blessed in Moscow was designed to represent Jerusalem as a city of multiple and diverse churches. In closing I turn to the Western tradition and provide a summary 
characterization of Gothic architectural icons of the Holy City and compare them to the Byzantine strategies.

Keywords: hierotopy, image-paradigm, Jerusalem, Christianity, iconography, Solomon's Temple, Byzantium, Holy City, sacred space.

\title{
ОБРАЗ-ПАРАДИГМА ИЕРУСАЯИМА В ХРИСТИАНСКОЙ ИЕРОТОПИИ
}

\author{
А. Д. Охоцимский \\ Научный центр восточно-христианской культуры, Москва, Россия \\ andrew_simsky@mail.ru
}

Образы-парадигмы - это не-илдюстративные образы сакрального. При конструировании сакральных пространств они работают как ментальные модели. При восприятии они актуализируются как эмерджентные образы, опирающиеся на организованную совокупность материальных, образных и смысловых компонентов сакральных пространств. Образ-парадигма нигде не изображён, но присутствует как видение, ментадьный образ, возникая из множества согласованных символических ассоциаций. В этой работе я пытаюсь разъяснить это нетривиальное понятие на примере образа Св. Града Иерусалима, который играет фундаментальную роль в христианской иеротопии. Св. Град Иерусалим - это многодикий синтетический образ, включающий как черты реального города-святыни, так и божественное видение Божьего Града на небесах. Суть Иерусалима в теофании. В нём - и центр мироздания, и полюс святости. Как Церковь в целом, так и отдельный храм всегда сопоставлялись с Иерусалимом - не столько формально-символически, сколько по сути и по функции, как место встречи с Богом. Пребывая в литургическом пространстве храма, верующие ощущают себя в Небесном Иерусалиме. В этом суть данного образа, который онтологически отличается от традиционной иконы. Если икона создаёт эффект присутствия святого в сакрадьном пространстве храма, то здесь требуется создать атмосферу Небесного Града, который сам по себе неизобразим. Это возможно путём создания так называемой пространственной иконь, которая представляет собой пространственный ансамбль элементов, наделённых сакральным смыслом, своего рода сакральную мультимедийную перформативную инсталляцию. Такой пространственной иконой является и сама дитургия, в которой образ Небесного Града присутствует как эмерджентный образ, создаваемый организованным образно-символическим ансамблем, элементы которого указывают на ключевые атрибуты Небесного Града. Актуадизация этого образа в сакральном пространстве возможна лишь потому, что образ-концепт Небесного Иерусалима уже известен верующим, и во время приобщения к сакральному простран- 
ству он как бы вспоминается. Для «напоминания» о Святом Граде используются разнообразные иконографические приёмы, включая изображение архитектурных элементов реального Иерусалима - города-реликвария Гроба Господня, а также использование идеализированной или даже фантастической архитектуры. Обсуждается возможная связь происхождения луковичных глав русских церквей с кувуклием Гроба Господня и с храмом Купола Скалы, а также образ Иерусалима как города многих церквей в архитектонике собора Василия Блаженного. В закдючение сопоставдяются архитектурные образы Св. Града в западно-европейской готической и в древнерусской традициях.

Ключевые слова: иеротопия, образ-парадигма, Иерусалим, христианство, иконография, храм Соломона, Византия, святой град, сакральное пространство.

DOI 10.23951/2312-7899-2018-3-101-113

The title of this paper features two terms that are likely unfamiliar to the reader: hierotopy and image-paradigm. Hierotopy is defined by the author of the concept, Alexei Lidov, as the creation of sacred spaces viewed as a special form of human creativity. It is thus a kind of art, and a wide variety of sacred spaces, such as churches and temples as well sacred cities and landscapes, are its products. The sacred space of hierotopy is broadly understood as the composite sum of its multifarious components, including not only architecture, icons and relics, but also all the performative opulence of devotional acts that transpire within it ${ }^{1}$.

Image-paradigms are religious image-concepts associated with sacred spaces, mental images that both inspire hierotopic creativity and are evoked in the minds of the beholders. They shape and inform the construction of sacred spaces as mental models. The 'paradigm' in imageparadigms is a kind of design, sketch, or outline understood along the lines of the original meaning of the Greek word $\pi \alpha \varrho \alpha ́ \delta \varepsilon \imath \gamma \mu \alpha^{2}$.

\footnotetext{
${ }^{1}$ Hierotopy, first defined and given shape by Lidov around the year 2000, now composes a popular academic field of its own. Lidov's own work in the first years has been summarized in his monograph [Lidov 2009 a]. An untold number of papers and seven thematic books have since been published on hierotopic subjects (see www.hierotopy.ru, wikipedia or [Simsky 2018]). The claim that hierotopy has come to constitute an independent field of study has recently been challenged by Zagraevsky [Zagraevsky 2018], which has opened up an ongoing debate in recent (and, possibly, future) issues of this journal [Simsky 2018].

2 The concept of image-paradigm was first introduced by Lidov [Lidov 2006, 42] and has subsequently been used in the analysis of the imagery engendered by sacred spaces [Lidov $2009 \mathrm{~b}$; Lidov 2014; Lidov 2017 a, 2017 b; Simsky 2013]. The study of Its theoretical aspects is challenging due to its complex character [Simsky 2016 a, 2016 b].
} 
Image-paradigms are non-pictorial images of the sacred. Although nowhere directly depicted, they are actualized as mental images through a manifold of concerted associations, taking shape in the viewer's imagination via an organized system of iconic, symbolic and typological elements of the sacred space. In this paper I set out to elucidate this complex notion by looking more closely at the example of one fundamentally important image-paradigm, namely, the Holy City of Jerusalem ${ }^{3}$.

Although every Christian city can be imbued with religious meaning and seen as sacred, the Holy City of Jerusalem is the Holy City par excellence. Its holiness is deeply rooted in the very bosom of the Christian faith. As a true image-paradigm, Jerusalem functions as a prototype for other Christian sacred spaces, particularly for churches.

What exactly does the word 'Jerusalem' mean in the context of the Christian faith? In fact, it can designate no less than five different cities:

1. The veterotestamental Jerusalem, the city of King David and Solomon's Temple, where the Ark of the Covenant was enshrined.

2. The New Jerusalem described in the visions of the prophets during the period of the Babylonian exile, following the city's destruction in $586 \mathrm{BC}$.

3. The restored Jerusalem, the city of Zerubbabel's and Herod's Temples, where Jesus was crucified, resurrected and ascended into Heaven. Just as before, this Jerusalem too was destroyed in 70 AD.

4. The Heavenly Jerusalem (Heb. 12:22; Gal. 4:26) of apocalyptic eschatological vision (Rev. 3:12, 21:10).

5. The Christian, or 'Constantinian' Jerusalem, the city-shrine of the Holy Sepulcher and a pilgrimage site.

These five Jerusalems appear differently through the lens of historical analysis, but they merge together in the religious mind into the single, unified and multifaceted City of God, which is at the same time both earthly and celestial. This Jerusalem is the 'navel' of the oikoumene, the seat of God and the source of all holiness. It is the center of hierophany where God's Glory is made manifest. It is remarkable that each successive destruction of Jerusalem triggers its interiorization. It never disappears. Even when destroyed, it lives on in religious consciousness as an image-concept ${ }^{4}$.

All its polymorphism notwithstanding, the key meaning of Jerusalem always remains the same: it is a place of God's immediate, living

\footnotetext{
${ }^{3}$ From among vast literature on the subject of Jerusalemite imagery in Christianity I would recommend two books [Rosenau 1979; Kuhnel 1987], as well as a paper by Lidov [Lidov 1998].

${ }^{4}$ As the term itself suggests, image-concepts are mental structures that comprise both a vision and a pure idea, thus merging the abstract and the sensual [Simsky 2016 b; Simsky 2017].
} 
presence. It is only logical that the Church as a whole, as well as individual churches, are continually identified with Jerusalem. This identification should be seen neither as a conventional symbolism, nor as a mere allegory, nor as a rhetorical device. Instead it is a deep relationship, a real identity that encapsulates the fundamental purpose and function of a church as a meeting place with $\mathrm{God}^{5}$. The Heavenly Jerusalem, a paradisiacal city, is manifestly present in each church so long as its future citizens - saved Christians - are assembled there. While partaking of the sacraments and integrating into the liturgical space, the faithful feel themselves to be in the midst of the Heavenly Jerusalem. This sense of standing in close proximity to the dwelling place of God has a patently holistic character, which clearly cannot be reduced to the level of a mere pictorial image.

Indeed, pictures can do a lot, but they cannot capture a sense of being somewhere in its completeness. One cannot depict an 'aura' of a place. Just to give an example, we can draw up the sketch of a building, but we cannot draw a 'home' - 'home' being understood not merely in a sense of a house, but of a bond, a complex of feelings and associations relating to 'being at home', that is a place so dear to us that the word 'sacred' seems applicable. The Heavenly Jerusalem is, in fact, a kind of home a destination yearned for in the afterlife, the foretaste of which is already available here and now - and palpably present in the sacred media of Christian churches. This foretaste is central to the perception of the image-paradigm of the Holy City. In order to actualize this imageparadigm, the sense of being there (or of being transported there) must somehow be evoked.

To properly transport oneself, or the eye of one's mind, into a different place, something other than direct pictorial representation is required. This is what's involved in the concept of the image-paradigm. A similar phenomenon in the realm of commercial image-making is the 'aesthetics of the atmospheres' [Böhme 2017] at work in theme restaurants and cafés, such as Hard Rock, Irish Pubs or Chess Café. In such a place, all the diverse aspects of the interior - the selection of music and the style of furniture and lighting, the images hanging on the walls and other exhibited objects - work together to form a certain atmosphere. To take one example, when entering one of the new, high-class "Starbucks Reserve" cafés, one passes into an entirely 'other' space, the space of a chic, convivial and hip café, a place frequented by poets, intellectuals,

\footnotetext{
${ }^{5}$ While this identification is particularly well established in the case of Gothic cathedrals [Stookey 1969; Recht 2008; Simsky 2016 c], Lidov has shifted the discussion towards an Eastern Orthodox context [Lidov 1998].
} 
bohemians and artists. Each detail of the design - from the Ella Fitzgerald and John Coltrane music to the sleek chairs and inviting, handcarved coffee tables - contributes to a unique and distinctly Starbucks ambience, thus conjuring its 'image-paradigm' in the minds of its clients and effectively transporting them into another, very sophisticated, caffeinated world ${ }^{6}$.

Pictures can help to create an ambience, but they are unable to represent it. Just to give one more example, imagine a wonderful majestic place or environment where people enjoy staying, say, a sea coast with a beach. If we hang a vacation photo of a beach on a wall of our office, it will serve as a reminder or souvenir, but it will not transport us there. Indeed, the very fact that the small photo presents only a single, meager fragment of the much larger, all-embracing elemental ambience of a seacoast clearly indicates that we actually are not there, that we are just in our office, with the sea being miles away. If anything, to imagine ourselves at sea, we have to close our eyes rather than open them.

Coming back from a general theory of images and responses to the domain of religious imagery, let us note that there is one more important reason why image-pictures cannot represent religious image-concepts, like that of the Heavenly Jerusalem. According to the usual Christian justification offered in defense of images, icons are allowed and even needed to help show us incarnate realities in a visible material form. As such, icons serve the purpose of representing Jesus, the Theotokos and the saints, as well as events and stories in which they participated. But icons are never meant to represent realities of a divine nature, although they sometimes attempt to do so. Such attempts often prove to be controversial and are typically not canonized. Hence, it comes as little surprise that no commonly accepted standard has ever existed in Eastern Christian iconography for the depiction of the Heavenly Jerusalem. It is, well, heavenly that is, ineffable, unrepresentable. The gist of the idea is not found in the authenticity of its shape, color or composition, but in the sublimity of the feelings that it evokes. Although a city, it is still very much a vision-city, accessible only to the eye of the mind. As in the above example with the beach vacation, in order to see it, one has to close one's eyes rather than open them. But it should still be possible somehow to stir up the image of the Holy City in the religious imagination. In what follows, we shall look at a number of strategies to conjure up Jerusalemite imagery - powerful but elusive - by means of visual arts.

\footnotetext{
${ }^{6}$ I am indebted to Brian Robertson for this 'tasty' illustration of how 'aesthetics of the ambience' works.
} 
One device, which was widely used in Medieval representations of the Last Judgement, was to prudently present the heavenly paradise by revealing only its entrance gates, such that one was able to peek into its brightly lit interior and see that it clearly resembled a city. Another technique, which turned out to be quite popular, was to represent the Celestial City by means of earthly architecture. In the famous St. Pudenziana mosaic, for example, the quadruplet of celestial living beings soars above the skyline of Constantinian Jerusalem (fig. 1). The latter can be identified by the Rotunda of the Resurrection as well as by the gemmed Golgotha cross erected in the Martirium. While contemplating this mosaic, one is likely to wonder, where exactly one is: in Heaven or on earth? Are we witnessing a sermon on the Mount or attending a hearing of the eschatological tribunal? No direct answer is given or available. In this icon, occupying the apsidal conch of one of the oldest Roman churches, the heavenly and the earthly merge together as completely, undividedly and paradoxically as in the very Sacrament of the Eucharist.

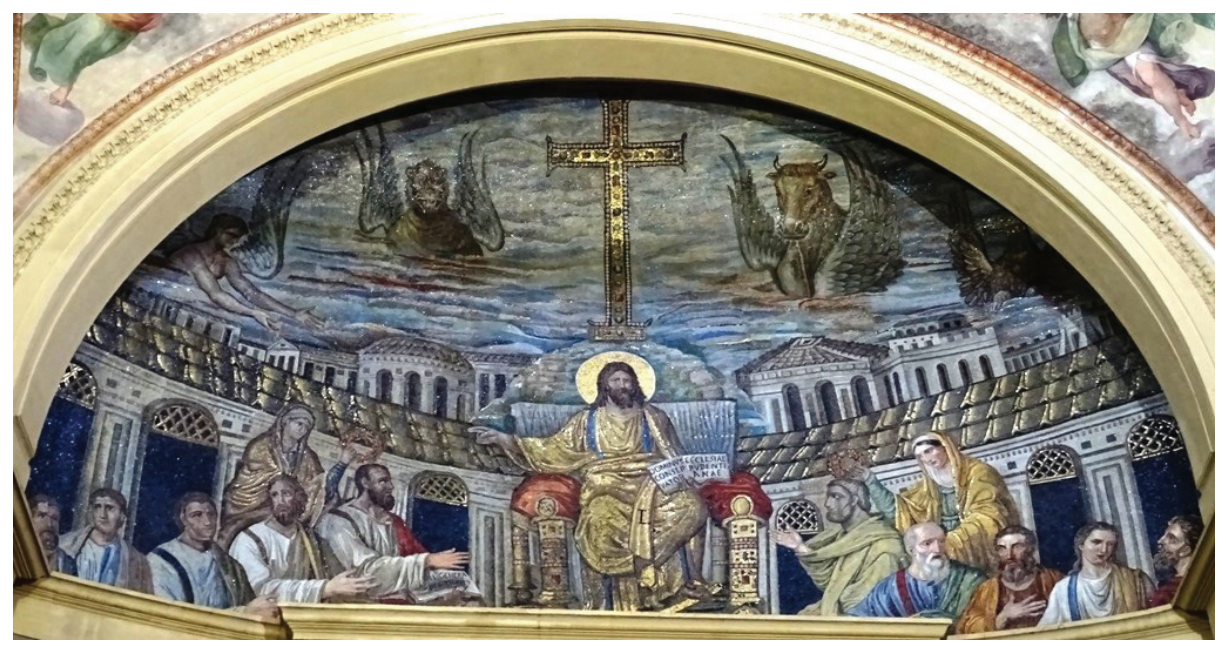

Fig. 1. The apse mosaic of the St. Pudenziana church in Rome, dating from the end of the $4^{\text {th }}$ century, with extensive restoration in the $16^{\text {th }}$ century

Of course, heavenly architecture does not have to be realistic. The delicate openwork structure of an idealized palace that is found in the St. George rotunda in Thessaloniki epitomizes the Eastern conception of theosis (fig. 2). The use of idealized and even fantastic architectural motifs turned out to become a major mode of Jerusalemite thematization in Eastern iconography. In all of these cases, only hints and elusive pointers are provided. The actual construction of the Celestial City is 
left to the imagination, with the visual art serving to provide merely an initial impulse.

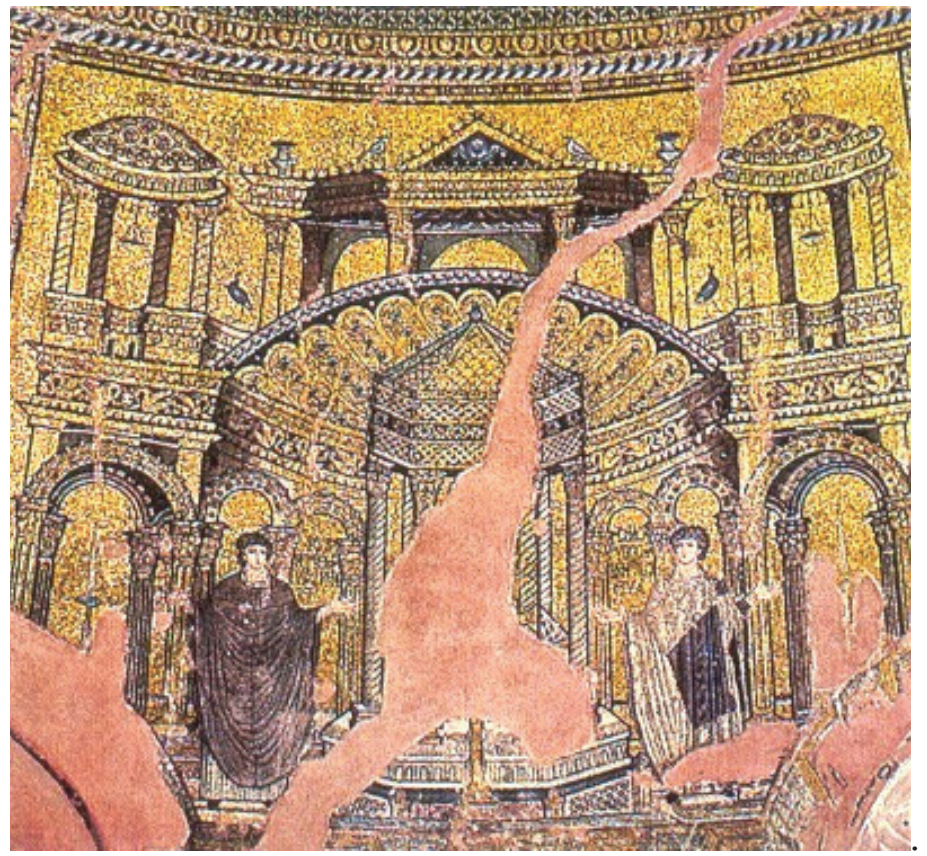

Fig. 2. A fragment of the lower tier of the dome mosaic in St. George's Rotunda in Thessaloniki, dating from the $4^{\text {th }}$ or $5^{\text {th }}$ century

Although Russian Orthodoxy is typically associated with Byzantium and Constantinople, Jerusalem was unquestionably a focal point of holiness in Medieval Rus as well. A famous Russian apocryphal poem "Golubinaya kniga" [Mochulsky 1887] directly declares Jerusalem to be "the father of all cities" and the Church of the Holy Sepulcher as "the mother of all churches". Striking examples of Jerusalemite motifs in architectonics and external decoration can be found in the $12^{\text {th }}$ century cathedrals of Vladimir, particularly the churches of St. Demetrius and the Intersession of the Holy Virgin on the Nerl. They are nearly cubic in form - a shape both of the Holy of Holies and the Heavenly Jerusalem and have three arches on each of the four sides. The motifs of their stone lacework represent the story of King David and the external decorations of Ezekiel's temple [Lidov 2013, 120-148]. Jerusalem was thus clearly a primary source of holiness for our ancestors as well ${ }^{7}$.

\footnotetext{
7 The Jerusalemite vector of Russian religious culture became even more pronounced in the $15^{\text {th }}$ and $16^{\text {th }}$ centuries during the long period of canonical schism with the Constantinopolitan Patriarchate, which lasted 83 years from 1479 to 1562 . By freely drawing from the ultimate source of
} 


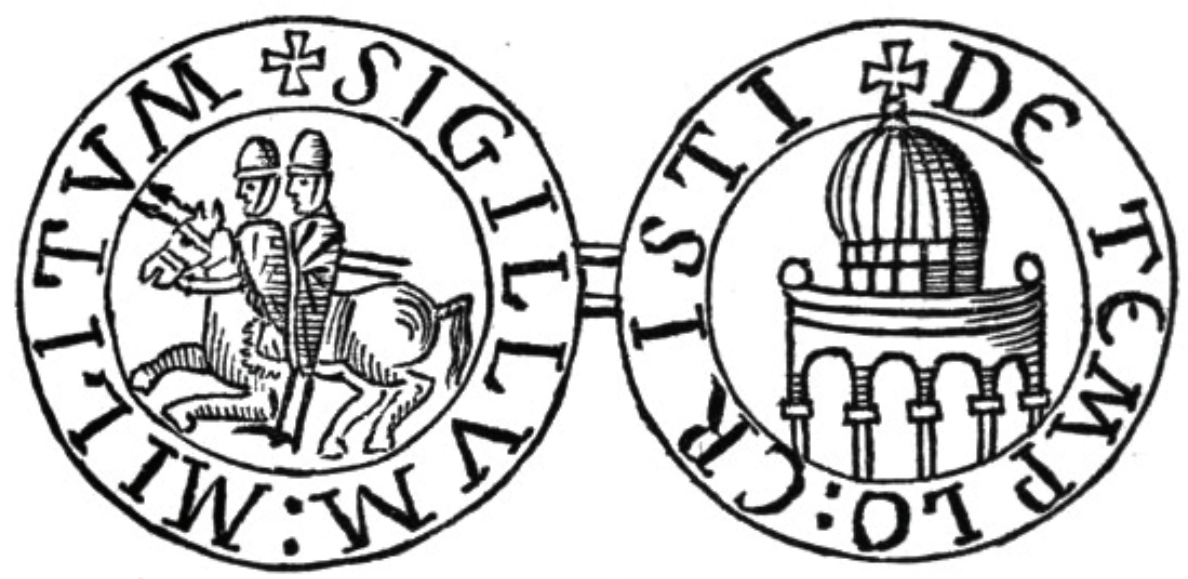

Fig. 3. The seal of the Grand Master of the Order of Knights Templar featuring the onion-domed Temple

The apt expression "mother of all churches" makes reference to a major stream of hierorotopic creativity - namely, the re-creation of holy spaces. Any Medieval church was in some way derived from the Jerusalemite 'mother church', becoming her child or even a kind of clone. The model of cloning was followed quite literally in the New Jerusalem Monastery near Moscow, for example, where not only the "mother of all churches", but also the broader topography of the Holy Land, was re-created. While this particular New Jerusalem remains rather exceptional in its size, scope and mimetic accuracy, Medieval Western Europe was studded with numerous re-creations of Christian Jerusalem, each conceptually similar, albeit more modest in scale [Lidov 2009c]. The same principle was at work in each Orthodox church as well: its 'prestol' (altar) was understood to imitate Christ's tombstone and was required to be equal in length $(1.75 \mathrm{~m})$, while the presence of the menorah in the sanctuary accentuated the special role of the church's altar space as a 'child' of the Holy of Holies.

It is quite likely that the now-iconic Russian onion domes were originally conceived as architectural icons of Jerusalemite temples specifically - the Eadicule of the Holy Sepulcher ${ }^{8}$ and Solomon's Temple; the latter at the times of the crusades came to be associated with the

holiness, the Russian Orthodox Church accentuated its sovereignty and its independence from the untrustworthy Byzantines, who were continually flirting with an idea of reuniting with Rome.

${ }^{8}$ Lidov has suggested that onion domes originated in graphic representations of the Eadicule's roof, which was pictured in illuminations as well as imitated in ecclesiastical furnishing, such as tabernacles and censers [Lidov 2013, 148-169]. 
octagonal mosque of the Dome of the Rock [Bondarenko 1998] (fig. 3) ${ }^{9}$. Although a single onion dome initially indicated a single church, in the famous Muscovite cathedral of St. Basil the Blessed, a new model of the Holy City has taken shape: a city of multiple and diverse churches (fig. 4). The intricate surface patterns of its eight onion domes (twisted, ribbed and scaled) drew upon contemporary graphical clichés used in representing Jerusalemite architecture. If this church was, in fact, built by Italian architects, as some have suggested [Melnik 2012] the importation of Western imagery into xenophobic Muscovy is not as surprising as it seems.

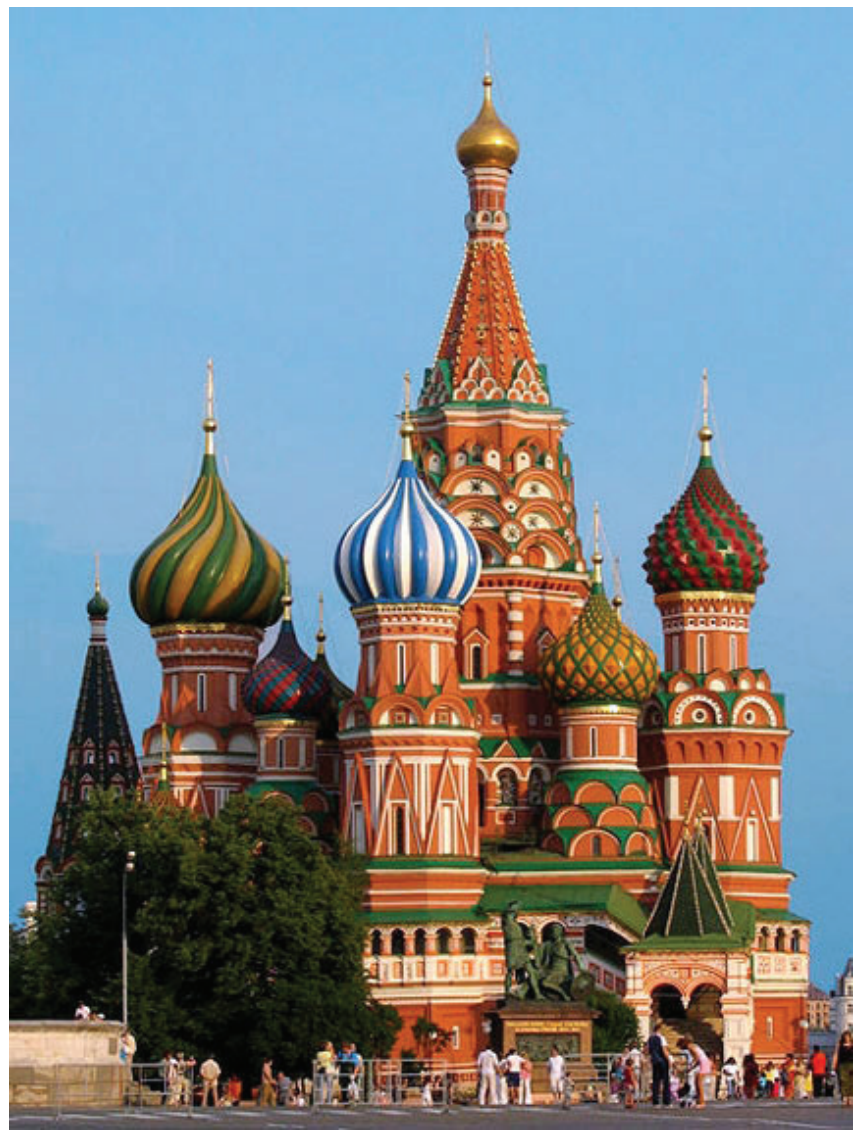

Fig. 4. St. Basil the Blessed cathedral in Moscow, dating from the second half of the $16^{\text {th }}$ century, originally, the Church of The Protective Veil of the Holy Theotokos on the Moat

\footnotetext{
${ }_{9}$ The Dome of the Rock was intentionally built by the Arabs on the site of Herod's Temple. It was converted into a Christian church by crusaders and announced to be a real Temple of Solomon, lending both its name and its aura to the Order of the Knights Templar and allowing the latter's seal to be used as a means to disseminate its peculiar onion-domed image across Christendom.
} 
In the West, the evolution of ecclesiastical architecture followed quite a different path. Gothic re-vision of the imagery of the Holy City was driven by multiple factors: urbanization, the emerging notion of historical progress and the onset of secularization [Simsky $2016 \mathrm{c}$ ]. The renewed Gothic architectural icon of the Holy City came to epitomize both the external features and the very spirit of the medieval city. Its rhythmic linear structures incarnated the march of sacred history, while its composite make-up embodied the Western urban motto, 'unity in diversity'. A comparison of Gothic cathedrals to Muscovite St. Basil's as well as Istra's New Jerusalem is instructive. It is clear that Russian Jerusalems represented an Eastern urban image, which was devoid of any rigid linear structure and tended to nestle imperceptibly into its non-urban environment.

Visions of Jerusalem are firmly embedded in Christian imagery. I have presented a handful of characteristic examples that demonstrate how the visionary idea of Jerusalem as the Heavenly City contributed to the designs of sacred spaces. In closing I would like to provide a brief and general overview of how Jerusalemite imagery is informed in religious consciousness and how it is embodied in the hierotopy of a traditional Christian liturgy. In this, I will be following along a path that I have already explored in greater detail elsewhere [Simsky 2016 b; Simsky 2017].

The formation of the mental image of the Holy City in a believing mind is a complex, lifelong process. The image belongs to the Christian tradition as a whole, and everyone sharing in this tradition inevitably comes to adopt this image for him-/herself. It is transferred to the believer by means of all the constituent aspects of religious experience: training, reading, prayer, liturgical life, mysticism etc. It gradually takes shape in the believer's mind and is perceived by him or her as part of an otherworldly, spiritual reality. When the faithful come to church, they are already prepared. The mental image of the Holy City is already formed in their minds and is ready to be actively engaged with.

Once inside a church and during the Divine Office, the mental image of the Holy City is actualized by a thoughtfully organized ensemble of iconic, symbolic and typological elements that point to key attributes of the Holy City. First, there is the building itself, a stone-made and rockfirm stronghold of faith with its vaults reaching up to the sky. The sacred space of the church is filled with the mystical presence of the saints. Its center is the Heavenly King himself, represented by an officiating priest, as well as by the Holy Mysteries on the throne / prestol situated inside the sanctuary. Sacred furnishings shimmering with gold and gems point to 
the material out of which the Heavenly Jerusalem is composed. The 'angelic choir' singing hymns and psalms, in which Jerusalem is frequently mentioned, most notably during Easter season, when the Paschal hymn, "Shine! Shine! O new Jerusalem!", is sung. The whole of this polyphonic orchestra merges together into the single distinct melody of the Heavenly Jerusalem, transporting the faithful into the Holy City.

\section{REFERENCES}

Bondarenko 1998 - Bondarenko I. On the origin of the onion shape of church domes. Narodnoe zodchestvo. Petrozavodsk, 1998. P. 105-113. In Russian.

Böhme 2017 - Böhme G. The Aesthetics of Atmospheres. Ed. by JeanPaul Thibaud. London, 2017.

Kuhnel 1987 - Kuhnel B. From the Earthly to the Heavenly Jerusalem. Representations of the Holy City in Christian Art of the First Millennium. Rome, Freiburg, Vienna, 1987.

Lidov 1998 - Lidov A. Heavenly Jerusalem. The Byzantine Approach. Jewish art. Jerusalem, 1998. P. 340-353.

Lidov 2006 - Lidov A. The Creation of Sacred Spaces as a Form of Creativity and Subject of Cultural History. Hierotopy. Creation of Sacred Spaces in Byzantium and Medieval Russia. Ed. by A. Lidov. Moscow. P. 32-58. In Russian.

Lidov 2009 a - Lidov A. Hierotopy: Spatial Icons and Image-Paradigms in Byzantine Culture. Moscow, 2009. In Russian.

Lidov 2009 b - Lidov Alexei. 'Image-Paradigms' as a Category of Mediterranean Visual Culture. A Hierotopic Approach to Art History. Crossing Cultures. Papers of the $32^{\text {nd }}$ International Congress in the History of Art. Melbourne, 2009. P. 148-153.

Lidov 2009 c - New Jerusalems. Hierotopy and Iconography of Sacred Spaces. Ed. by A. Lidov. Moscow, 2009. In Russian.

Lidov 2013 - Lidov A. Icons. The World of Holy Images in Byzantium and Rus. Moscow, 2013. In Russian.

Lidov 2014 - Lidov A. The Temple Veil as a Spatial Icon. Revealing an Image-Paradigm of Medieval Iconography and Hierotopy. IKON. 2014. 7. P. 97-108.

Lidov 2017 a - Lidov A. The Priesthood of the Virgin Mary as an ImageParadigm of Christian Visual Culture. IKON. 2017. 10. P. 9-26.

Lidov 2017 b - Lidov A. Sacred Waters in Ecclesiastical Space. The Rivers of Paradise as an Image-Paradigm of Byzantine Hierotopy. Holy Water 
in the Hierotopy and Iconograhy of the Christian World. Ed. by A. Lidov. Moscow, 2017. P 159-183. In Russian.

Melnik 2012 - Melnik A. Who has built the Intercession-on-the-Moat Cathedral in Moscow? Reports of the Rostov Museum. 2012. 19. P. 142154. In Russian.

Mochulsky 1887 - Mochulsky V. Historical and Literary Analsysis of poetry of 'Golubinaya kniga'. Warsaw, 1887. In Russian.

Rosenau 1979 - Rosenau H. Vision of the Temple. The image of the Temple of Jerusalem in Judaism and Christianity. London, 1979.

Recht 2008 - Recht R. Believing and seeing. The art of Gothic cathedrals. Chicago, 2008.

Simsky 2013 - Simsky A. The Image-Paradigm of the Fire of God in the Bible and in the Christian Tradition. Hierotopy of Light and Fire in the Culture of the Byzantine World. Ed. by A. Lidov. Moscow, 2013. P. 4581. In Russian.

Simsky 2016 a - Simsky A. Image-paradigms in Religious Culture. Interdisciplinary researches of culture. 2016. 8. P. 36-44. In Russian.

Simsky 2016 b - Simsky A. Image-paradigms in Hierotopy: Ontological and Functional Aspects. Diogenes' Lantern: The Human Being in Diversity of Practice (International Anthropological Journal). 2016. Vol. 2. P. 355-374. In Russian.

Simsky 2016 c - Simsky A. The Imagery of the Gothic Cathedral: a Hierotopic Approach. ПРАЕHMA. Journal of visual semiotics. 2016. 3 (9). P. 9-24. In Russian.

Simsky 2017 - Simsky A. Image-paradigms in Hierotopy: Sacred Spaces as Communicating Media. Annual conference of the European Association of the Study of Religion EASR-2017. Leuven, 2017. URL: https:// www.academia.edu/34663306/Image-paradigms_in_Hierotopy_ Sacred_Spaces_as_Communicating_Media.

Simsky 2018 - Simsky A. Hierotopy as Principle and Instrument. ПРА ЕНМА. Journal of visual semiotics. 2018. 2 (16). P. 62-85. In Russian.

Stookey 1969 - Stookey L. The Gothic Cathedral as the Heavenly Jerusalem: Liturgical and Theological Sources. Gesta. 1969. 8, 1. P. 35-41. Zagraevsky 2018 - Zagraevsky S. About Scientific Validity of Hierotopy. ПРА ЕНMA. Journal of visual semiotics. 2018. 1 (15). P. 49-69. In Russian. 